retaining a general identity of the subsequent ulcerative process, so all the facts that can be brought together respecting the ulcer of the stomach, point to a similar conclusion. It is only thus we can explain its ascertained relation to many diseases, and to various physiological conditions. Agne, fever, or the vascular disturbances of female puberty might, perhaps, cause ecchymosis; but to convert this effusion into a spreading ulcer, would require a process of absorption which no mere extravasation would explain. The influence of old age, privation, and fatigue, again, throw little light on the local change that ushers in the ulceration, but exactly concur with the known efficacy of these circumstances in the promotion of ulceration elsewhere. In like manner, to grant that the circumstances of digestion often retard the healing of a gastric ulcer, is to concede nothing more than may be observed in an ulcer of the leg, where such physical circumstances as posture, pressure, and the like, equally influence the result. Nay, more, that the analogy extends to the minutest details, is weli shown by comparing the gastric and the cutaneous ulcer of the young female. During the epoch which immediately follows the access of puberty in the fenale, both these varieties of ulceration-the nlcer of the stomach and the ulcer of the leg-are marked by an absence of reaction in the lesion, and are generally followed by cachexia, by more or less amenorrhcea, and, lastly, by an aggravation of the local symptoms at the menstrual periods. *

\section{HISTORY OF THE}

\section{DISCOVERY OF THE GANGLIA AND OTHER NERVOUS STRUCTURES OF THE UTERUS AND HEART.}

B× ROBERT LEE, M.D., F.R.S.,

FELLOW OR THE ROXAL COLLEGE OF PHYSICLANS, OBSTETRIC PHYSICIAN TO ST. GRORGE'S HOSPITAL, 1 ND PHYSXCIAN TO THE BRITISH LIING-IN HOSPITAL.

From the functions of the human uterus, Galen inferred that it must be supplied with nerves; but they are extremely small, he says, compared with the size of the organ. He knew that the uterus is supplied with branches from the great sympathetic and sacral nerves. In 1559, Vesalius stated that small branches of nerves proceed to the neck of the uterus on each side from the sacral nerves, and that the superior part of the aterus receives minute branches of nerves from the great sympathetic. + The nerves of the uterus were described by various writers during the latter part of the sixteenth century, but in an equally or still more imperfect manner. The anatomists of the seventeenth century also allude to them, but with no greater accuracy and precision.

In 1664, Willis described the plexuses formed on each side of the uterus, bladder, and rectum, + by the great sympathetic

* Compare the anthor's essay, British and Froreign Review, July, 1836, pp 170,171 ; and Critehett "On Ulcers of the Lower Extremity," p. 107. et seq. London, 1819

$\dagger " \mathrm{Ab}$ ossis sacri nerrorum paribus utrinque etiam nervi propagantur temuibus surculis in uteri potissimum cervicom, et circa humiliorern fund sedem excurrentes. Ad elatiorem porro fundi regionem, stubinde nervuli perquam graciles diffunduntur, a sexti nervorum cerebri paris ramis dissecti,
qui costarum exporriguntur radicibus. Verum, ut hi nervali pertenues albicantes que sunt, et pinguibus membranis, ut prius commemorati, suffulciuntur; it a quoque inter secandum difficulter occurrunt."-Comment., lib. $i$. Hippocrat. de Morbis Vulg., p. 299. Basil, 1559.

"Duo antem humiliores nervi, qui sexti septinnique parium propagines sunt in ani musculos digeruntur. Ad hæc, in uteri cervicem frequenti sobole, ubi etiam in virorum vesicæ cervicem, penemve pertinent. Nam vesice ac uterl idem fundus plerumque nervulos ab illis mutuantur ramis qui a sexto, pari nervorum cerebri costarum radicibus sub tunica costas succingente exporriguntur?"

¥ "A plexn vicino infimo (scilicet nervi intercostalis) duo nervi prodiuntes, atque in pelvim dimissi, binos ibi plexus, sc. in alterutro latere unum efíciunt, in quos nervi ab osse sacre aseiti, et prioribus inosculati coeunt; e quibus vero nervi in partes adjacentes distributi, singuls excretionibus-sc., urinæ, stercoris, et seninis, illic loci factis prospieiunt; nam duo nervi intestinif recti extrenitatem subeunt, totidemque in nterm aut prostatas; unus autem, isque insignis in vesieam defertur." -Willis, Nervorum Descriptio et Usus, p. 183 . Londion, 1664 .

"A plexu abdominis infimo, dno nervi in pelvim dimissi, illie utrinque nervum vertebralem insignem recipiunt; adcoque duos plexus nempe unum in alterutro latere constituunt. Fi plexus prope ostia, ductibus precip'is excretoris preposita, collocati, illis seclunendis, resermandisve inserviunt utrique ramus vertobralis velut subsidiarius atcenit; quo quidem efficitur, ut preter spirituum copias adauctas, conm als his plexibus emanantium actus aliqualem spontinei evadant. Quo vitu et quem ob finem nervas $a b$ utroque plexu ascendens, intestino recto impenditur, modo ostensum erat, and sacral nerves. Haller appears to have been the first anatomist who described the origin and course of the spermatic nerves from the renal plexus to the ovaria and Fallopian tubes, and he traced the hypogastric and sacral nerves to the uterus, bladder, rectum, vagina, and parts around, more fully than any anatomist had previously done.*

J. G. Walter represented on his first Plate only a few small filaments 'of nerves passing into the lower part of the orifice and cervix of the unimpregnated uterus from the upper part of the plexus described by Willis and Haller. The fundus and body of the uterus are left covered with peritoneum, and the spermatic nerves have not been delineated. Professor Walter published a Treatise denying the muscularity of the uterus, and assribing its contraction after child-bearing to the contraction of the arteries. $t$

Dr. William Hunter published a description of the nerves of the unimpregnated uterus, "such as they appeared to him in a female subject carefully dissected for that purpose." After describing the course of the spermatic and hypogastric nerves, he says, "The hypogastric nerve passes round the side of the pelvis, between the peritoneum and the hypogastric vessels, and upon the inside of the ureter. At the middle of the side of the pelvis, where the hypogastric vessels divide, the nerves split into a double range of branches-viz., anterior and posterior. The posterior range goes to the side of the rectum, some branches passing to the back part, and others to the fore part of the gut; and the first and uppermost of these branches are manifestly reflected upwards upon the gut, directing their course towards the colon."

The anterior range of branches is the largest, and may be considered as the continuation of the trunk of the hypogastric nerve, in the form of a plexus. Where the hypogastric vessels are passing to the side of the uterus and vagina, this nerve, situated behind them, spreads out in branches like the portio dura of the seventh pair, or like the sticks of a fan, with many communications which are sent to the whole side of the uterus and vagina. The uppermost branches pass upwards on the duplicature of the broad ligament towards the fundus uteri. The branches, as they go to the lower part of the organ, pass less obliquely, then horizontally, and the lowest of all run downwards on the side of the vagina. The greatest crowd or number of these branches go to the os tincæ and the adjacent parts of the uterus and vagina."

"I cannot take upon me to say," adds Dr. Hunter, "what change happens to the system of uterine nerves, but I suspect them to be enlarged in some proportion as the vessels are."

"The uterus," says Mr. John Hunter, "in time of pregnancy, increases in substance and size probably fifty times beyond what it naturally is, and this increase is made up of living animal matter, which is capable of action within itself. I think we may suppose its action more than double, for the action of every individual part of this viscus, at this period, is much increased, even beyond its increase in size, and yet we find that the nerves of this part are not in the smallest degree increased. This shows that the nerves and brain have nothing to do with the actions of a part, while the vessels whose uses are evident increase in proportion to the increased size : if the same had taken place with the nerves we should have reasoned from analogy."

In another part of his works, Mr. Hunter again denies that the nerves of the uterus are enlarged during pregnancy.

Porro bini utrinque descencentes in uteri collum aut prostatas feruntur. Proculdubio quicquid sensus vel motus circa actus venereos perficitur, spirituum per hos nerros influxui debetur."-Idem opus, p. 203.

" $U t$ in viris, sic in feminis, multiplex est horum nervorum origo. Primi, supremi nasenntur ex plexu renali. Eum rami ex ganglio magno orti componunt, cum ramis a truneo nervi intercostalis profunde pone aortam et venam renalem aceedentibus, aliisque ex plexu ab arteria mesenterica ad infexiorem sex mesocolicam, et ante et pone venam descendentibus. Inde prælongus nervus pone venam renalem sinistram ante aortam it cum funiculo spermatico deorsum et augetur ab intercostali trunco sub prima ossis sacri vertebra, et in ovarium descendit. Alii nervi oriuntur ex mesocolica plexu, et ab intercostali trunco, et ex spermatico; ita plexus nascitur, qui ante aortam descendit, et ante truncum iliacum sinistrum reteque facit in cartilagine sub ultima vertebra lumborum, ex quo in pelvim rami deseendunt, et ad uterum et ad vesicam magnis truncis veniunt. Alii per ligamentum latum ad tubam et ovaritum tendunt. Sed ab eodem plexu alii surculi cum quarto ossis sacri nervo uniuntur, et iidem numerosi nterum adeunt et vesicam, aliusque a quarto saero anterior ad vaginan. Denique nervus qualis ad penem, et ischi adico natus, circumductus en tertio et quarto nervo sacro, perinde eirco os ischiji et pubis ad extremam vaginam et vulvam, cjusque musculos et clitoridem venit, perque ejus dorsum incedit. Hos nervos yere vidi, pluresque esse non
repugno, neque enim hae historia plena habetur."-Elem. Ihysiolog., tom. viii. p. 135. Berme, 166:

+ Nervi uteri e plexu (hypogastrico) orti : ambulant hi nervi subtilissimi facti ad eervicem et os uteri ubi aciei oculorum sese subducunt."-(Tabule Nervorum Thoracis et Abdominis. Reiolen, folio, 1783, p. 4.)

$\mp$ An Anatomical Teseriptinu of the Human Gravid Uterus and its Contents, by William Hunter, M.D., p. 21. London: 1794.

s The Works of John Irunter. Vol, iii., p. 117, 1837. 
Professor Tiedemann, in 1822, published a description of the nerves of the uterus, with two engravings. In the first plate, the spermatic nerves are seen on both sides, accompanying the spermatic arteries to the ovaria. The spermatic veins have not been represented, and it is not stated whether any nerves accompany these veins to the ovaria. The uterine arteries are seen running along the posterior surface of the uterus, and anastomosing near the ovaria with the spermatic arteries. The uterine nerves proceeding from the hypogastric plexuses are seen accompanying the uterine artery, and spreading out on the posterior surface of the uterus, like the branches of a tree, nearly in the same manner as represented by De Graaf; the uterine veins have been removed, and all the nerves which accompanied them. The fundus and body of the uterus, down to a line drawn across it, a little lower than the ovaria, are covered with peritoneum. Some small branches proceeding from the superior part of the left hypogastric plexus are seen accompanying the uterine artery, and spreading in an arborescent form on the side of the uterus. The uterine veins and nerves which covered them are also not represented.

In 1823, Professor Lobstein stated that the uterus, both before and after conception, had a very scanty supply of nerves: "Rarissime in uteri substantiam tum vacui tum gravidi sese immittere videntur nervorum surculi.'

Langenbeck published, in 1826, a plate of the unimpregnated uterus, in which he has represented the spermatic nerves passing with the arteries between the broad ligaments to the ovaria and uterus; a hypogastric plexus, and another nervous plexus formed by these and by branches from the sacral nerves, which supply the rectum, vagina, and uterus.

In 1829, Professor Osiander affirmed that the nerves of the human uterus had never been seen either by himself or by any other anatomist, and that he had been deceived by the authority of scientific persons when he stated that nerves were spread over the whole uterus. "Although it is very probable that the uterus possesses nerves (nervi uteri), still hitherto they have not been satisfactorily demonstrated, either as regards their number or their nature. I myself, like others, deceived by the authority of more scientific persons, formerly stated that nerves were spread over the whole of the human uterus, since I believed that more skilful anatomists than myself had really seen them; for example, Walter, who speaks so confidently of nerves which accompany the larger arteries. But I know now that they have not been seen by others any more than by myself, and I can only assume that the uterus, as an irritable organ, must possess nerves. But I have not seen, and it certainly does not possess any nerves that are easily demonstrable by the scalpel, and still less any large branches. But what we have not yet seen may subsequently be discovered. And those who have sufficient opportunities, and the requisite dexterity to examine pregnant and unimpregnated uteri should zealously endeavour, by repeated dissections, to discover the uterine nerves, and especially to trace the lumbar and sacral nerves towards the uterus, as it is probable that if nerves do go to the uterus, they, like the arteries, are much larger during pregnancy than those in the unimpregnated state." *

On the 8th of April, 1838, whilst engaged in dissecting a gravid uterus of seven months, I observed the trunk of a large nerve proceeding upwards from the cervix to the body of the uterus, with the right uterine vein, and sending off branches in its course to the posterior surface of the uterus, some of which accompanied the veins, and others appeared to be in serted into the peritoneum. A broad band, resembling a plexus of nerves, was seen extending across the posterior sur face of the uterus, and covering the nerves about midway from the fundus to the cervix. On the left side, a large plexus of nerves was seen surrounding the uterine veins, where they were about to enter the hypogastric vein. From this plexus, three large trunks of nerves, which increased in size as they ascended to the fundus uteri, were seen accompanying the uterine vein. From the nerve situated on the posterior surface of the vein, numerous filaments passed off towards the mesial line; as, on the right side, some following the smaller veins on the posterior surface of the uterus, and others becoming inti mately adherent to the peritoneum. The largest of these nerves accompanying the uterine vein was traced as high as the part where the Fallopian tube enters the uterus, and there it di vided into numerous filaments which plunged deep into the muscular coat of the uterus along with the vein. A large fas ciculated band, like a plexus of nerves, was also seen on the left side, under the peritoneum, crossing the body of the uterus, and several branches, apparentlv nervous, proceeding from the * Hondbuch der Endbindungskunst, Erster Band. Zweite Auflage. Tubingen, 1829. band, were distinctly continuous with some of the smaller branches of nerves accompanying the uterine veins. The preparation of the parts was placed in the Museum of St. George's Hospital on the lst of October, 1838. Several eminent anatomists to whom I showed the preparation thought that I had been misled by appearances, and that they were absorbent vessels accompanying the veins and tendinous fibres spread across the posterior surface of the nterus. They all acknowledged that they had never seen nor dissected the nerves of the uterus, either in the hunan subject or any of the lower nimals.

Before making this observation, I had been accustomed, like other practitioners, to speak of the pains of labour and uterine action and uterine sympathies, without attempting to explain them. In the operation of turning, I had often experienced the prodigious muscular power which the uterus is capable of exerting, and had witnessed, in cases of protracted labour, how long its actions were sustained without exhaustion; but I cannot recollect ever having put to myself, before that time, the question-From what source does the uterus derive the great sensibility and contractility which it exhibits in the process of parturition, and how does it exert by sympathy, especially during pregnancy, delivery, and in the puerperal state, such an extraordinary influence over the brain and the whole nervous system?

(To be continued.)

\section{HISTORY AND PRACTICE OF URETHRO. PLASTY.}

BY HENRY THOMPSON, M.B., F.R.C.S.

HOMOBATY SURGEON TO THE MARYLEBONE INFIRMARY, ASSISTAYTSURGBON TO UNIVRRSTY COLLTEE HOSPITAL.

\section{No. II.}

Soov after the occurrence of the two cases recorded by Cooper and Farle in nur own country, Delpech, of Montpellier, performed a urethroplastic operation, which he detailed in his work on Clinical Surgery.* In this case there had been loss of substance in the perinæum, and through the opening so formed all the urine issued. The borders were revived, a flap adapted from the groin, and fastened by interrupted sutures, and a gumelastic catheter was retained in the bladder. On the third day the flap became gangrenous, and ultimately entirely sloughed. Subsequently some contraction of the orifice was induced by caustic applications, but the man was not much benefited by their employment.

The writings of Dieffenbach, which present us with a most complete systematic history of a large practical experience in the exercise of plastic surgery, including urethroplasty as an important division of the general subject, come next under review. This distinguished surgeon recorded many of his observations in the form of papers or memoirs, which were published at Berlin between the years 1829 and 1834 , in four parts, and were entitled "Chirurgische Erfahrungen." Many of his earlier experiences were failures, and it was only after a long and patient perseverance in the endeavour to test the value of various operative procedures that his efforts were crowned with success. Subsequently, the results of his practice were recorded in "Oppenheim's Journal," before referred to; in the "Handbuch der Plastichen Chirurgie," by Zeis, published at Berlin in 1838; in his own work on "Operative Surgery," Leipsic, 1845; and, more fully still, in a volume devoted to plastic surgery, and dedicated to him, by Drs. Fritze and Reich, published at Berlin, also in 1845. From these sources chiefly have been selected the following modes of proceeding, as those which appear to have been the most generally applicable, and the most successful in their results.

In dealing with the antescrotal fistule which were too large to be remedied by the "lace suture," described in a previous paper-that is to say, such, for example, as would permit the introduction of a full-sized catheter-Dieffenbach tried the following method, and generally with but indifferent success. It is briefly given here because it formed the stepping-stone to a modification of the operation which was much more perfect in its results.

A large catheter having been introduced into the bladder, the rounded orifice of the fistula is converted into a lozenge-

* Chirurgie Clinique de MIontpellier, par le Prof. Delpech, tome ii., pp. 581-4. Paris, 1828. 